\title{
Is axial shape of distal femur different in normal and osteoarthritic female patients?
}

\author{
Normal ve osteoartritli kadın hastalarda distal femurun aksiyel şekli farklı mıdır?
}

\author{
Namık Şahin, MD., PhD., ${ }^{1}$ Senem Turan Özdemir, MD., PhD., ${ }^{2}$ Gökhan Ocakoğlu, PhD., ${ }^{3}$ \\ İlker Ercan, PhD., ${ }^{3}$ Teoman Atıcı, MD., ${ }^{4}$ Ünal Kurdoğlu, MD. ${ }^{5}$ \\ 'Department of Orthopedics and Traumatology, Bursa Yüksek İhtisas Training and Research Hospital, Bursa, Turkey \\ ${ }^{2}$ Department of Anatomy, Medical Faculty of Uludağ University, Bursa, Turkey \\ ${ }^{3}$ Department of Biostatistics, Medical Faculty of Uludağ University, Bursa, Turkey \\ ${ }^{4}$ Department of Orthopedics and Traumatology, Medical Faculty of Uludağ University, Bursa, Turkey \\ ${ }^{5}$ Department of Radiology, Bursa Yüksek İhtisas Training and Research Hospital, Bursa, Turkey
}

\begin{abstract}
Objectives: This study aims to investigate whether the axial shape of the distal femur is different between normal and osteoarthritic female knees using statistical shape analysis.

Patients and methods: A total of 126 knee magnetic resonance images of 126 female patients were examined in this study conducted between May 2013 and May 2014. Patients were divided into two groups as study and control groups. The study group consisted of 41 patients (median age 65 years; min. 36 - max. 88 years) who were determined to have knee osteoarthritis, while the control group consisted of 85 patients (median age 43 years; min. 20 - max. 81 years) without knee osteoarthritis. Anatomic and constructive landmarks were selected and marked on each two-dimensional digital image in the axial section of the distal femur. The mean axial shapes of the distal femur were compared between the groups by statistical shape analysis. Shape deformations were investigated by thin plate spline analysis.
\end{abstract}

Results: There were significant differences between the groups regarding the axial shape of the distal femur. Maximal deformation was observed in the femoral notch area.

Conclusion: This study showed that there are deformations in the axial shape of the distal femur in female patients with knee osteoarthritis. Further studies are required to determine whether these differences are important for implant design and surgical technique of total knee replacement.

Keywords: Distal femur; knee; osteoarthritis; shape analysis.
ÖZ

Amaç: Bu çalışmada normal ve osteoartritli kadın dizlerinde distal femurun aksiyel şeklinin farklı olup olmadı̆̆ 1 istatistiksel şekil analizi kullanılarak incelendi.

Hastalar ve yöntemler: Mayıs 2013 - Mayıs 2014 tarihleri arasında yapılan bu çalışmada toplam 126 kadın hastanın 126 diz manyetik rezonans görüntülemesi incelendi. Hastalar çalışma ve kontrol grubu olmak üzere iki gruba ayrıldı. Çalışma grubu diz osteoartriti olduğu belirlenen 41 hastadan (ortanca yaş 65 yıl; min. 36 maks. 88 y1l), kontrol grubu ise diz osteoartriti olmayan 85 hastadan (ortanca yaş $43 \mathrm{y}$ ıl; min. 20 - maks. 81 yıl) oluştu. Anatomik ve yapısal belirteçler distal femurun aksiyel kesitinde her iki boyutlu dijital imaj üzerinde seçildi ve işaretlendi. Distal femurun ortalama aksiyel şekilleri istatistiksel şekil analizi ile gruplar arasında karşılaştırıldı. Şekil deformasyonları ince levha eğrisi analizi ile incelendi.

Bulgular: Distal femurun aksiyel şekli bakımından gruplar arasında anlamlı farklılıklar vardı. En fazla deformasyon femoral çentik bölgesinde gözlendi.

Sonuç: Bu çalışma diz osteoartritli kadın hastalarda distal femurun aksiyel şeklinde deformasyonlar olduğunu göstermiştir. Bu farklılıkların total diz protezinde implant tasarımı ve cerrahi teknik açısından önemli olup olmadığını belirlemek için daha ileri çalışmalar gerekmektedir.

Anahtar sözcükler: Distal femur; diz; osteoartrit; şekil analizi.

- Received: February 15, 2016 Accepted: May 05, 2016

- Correspondence: Namık Şahin, MD. Bursa Yüksek İhtisas Eğitim ve Araştırma Hastanesi, Ortopedi ve Travmatoloji Kliniği, 16330 Yıldırım, Bursa, Turkey. Tel: +90 224 - 2955000 Fax: +90224-2955497 e-mail: sahinnamik@yahoo.com 
Morphometrics is a field concerned with studying variation and change in the form (size and shape) of organisms. Morphometrics can also be defined as the quantitative analysis of a biological form. Statistical shape analysis is a method used for modern morphometric analysis and has recently become more important in the medical and biological sciences. Currently, an organ or organism's appearance or shape is used as input data in the development of imaging techniques. ${ }^{[1]}$

Osteoarthritis (OA) is a process that is affected by the etiology of many systemic and local factors. ${ }^{[2,3]}$ It is widely believed that risk factors which alter the mechanical environment of the knee joint may cause knee OA. However, many individuals without risk factors will develop OA later in life, leading to the hypothesis that slight differences in joint mechanics, driven by variability in joint anatomy is responsible for OA onset and progression. ${ }^{[4]}$ Although the relationship between $\mathrm{OA}$ and coronal and sagittal alignments of lower extremities have been studied in detail, there is limited information on the effects of morphological differences in the bones of the knee joint on knee OA. Furthermore, studies that investigate the role of axial shape of the distal femur in knee $\mathrm{OA}$ are limited.

Most studies about the morphology of the distal femur are related to the examination of linear and geometric properties of anatomical landmarks. In this context, much research has been performed with the intent of fully describing the morphometric measurements of the distal femur. ${ }^{[5,6]}$ But to the best of our knowledge, no studies have been based on statistical shape analysis for investigating morphologic features in the axial plane of the distal femur in normal and osteoarthritic patients. The aim of this study was to investigate whether the axial shape of the distal femur is different between normal and osteoarthritic knees in women using statistical shape analysis on magnetic resonance imaging (MRI) scans of the knee.

\section{PATIENTS AND METHODS}

A total of 126 knee MRIs of 126 consecutive female patients were examined in this study conducted between May 2013 and May 2014. The patients were divided into two groups: the study group, which consisted of 41 patients who received an MRI after bilateral standing anteroposterior (AP) radiograph for degenerative $\mathrm{OA}$ and showed $>$ grade 2 KellegrenLawrence OA from a bilateral standing knee AP radiograph (median age 65 years; min. 36 - max. 88 years), and the control group, which consisted of 85 patients were determined to have $\leq$ grade 2 Kellegren-Lawrence OA who received an MRI due to suspicion of ligament injury due to trauma (median age 43 years; min. 20 - max. 81 years). None of the patients had a history of fracture around the knee, full ligamentous injury or inflammatory arthropathy. The study protocol was conducted in accordance with the Declaration of Helsinki (2008) and approved by the Ethic Committee of Bursa Yüksek İhtisas Training and Research Hospital. All patients signed informed consent forms for the knee MRIs to be taken.

Images were taken on a 1.5-Tesla scanner (GE Medical Systems, Milwaukee, WI). Fast spin echo images (repetition time $[\mathrm{TR}]=2,600$; echo time $[\mathrm{TE}]=$ 35.0) were obtained from above the patella to below the tibial tubercle. The standard clinical protocol was used for MRI sections of the knees in full extension, and axial sections were constructed on a parallel plane to the joint surface of the tibia. The field of view was $20 \mathrm{~cm}$, and the slice thickness was $4.5 \mathrm{~mm}$ with a $1.5 \mathrm{~mm}$ interslice gap. The MRI sections were examined and by using consecutive scans which showed the lateral epicondyle and/or the sulcus of the medial epicondyle, the most prominent point of the lateral epicondyle and the deepest point of the sulcus were determined. This slice was used for the measurements.

\section{Collection of two-dimensional distal femur landmarks}

Data from the axial distal femur were collected from the two-dimensional digital images. Standard anthropometric landmarks were selected and marked on each digital image using tpsDig 2.04 software (Rohlf 2005). In addition to the standard

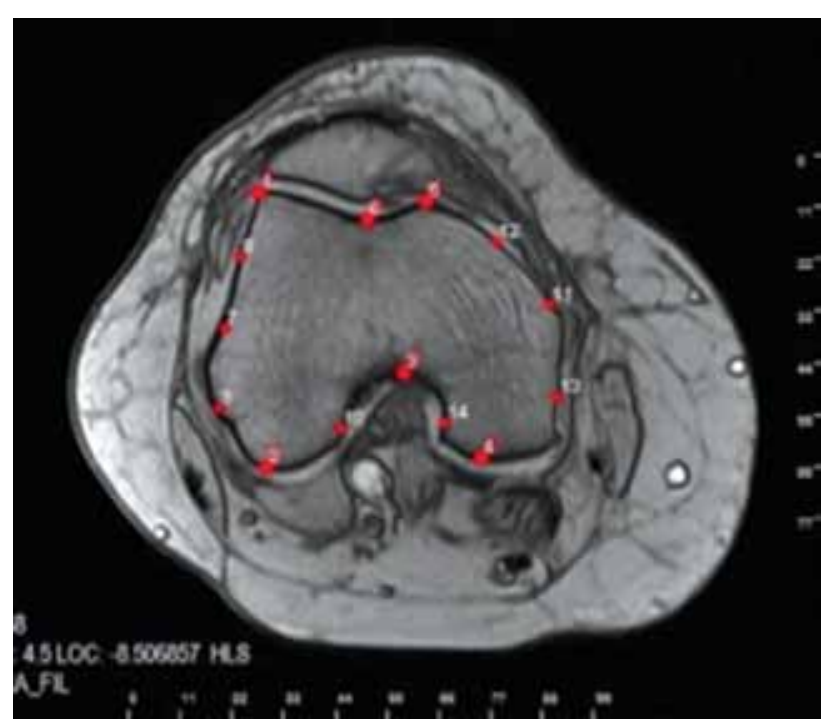

Figure 1. Landmark markings on axial section of distal femur. 
anthropometric landmarks, constructed landmarks were determined and used to better assess regional shape differences. Six anatomic and eight constructive landmarks were marked on the images (Figure 1). The descriptions of these landmarks are found in Table 1.

\section{Statistical analysis}

A generalized Procrustes analysis was used to evaluate the shapes. The homogeneity of the variance- covariance matrices was examined using the BoxM test. Because the variance-covariance matrices were not homogeneous, the James $F_{j}$ test based on a resampling procedure was performed for shape comparisons.

To obtain the overall measurements of shape variability in the groups, we compared the root mean square of Kendall's Riemannian distance (rho) to the mean shape.

\section{TABLE I}

Description of landmarks used in present study. Landmarks 1-6 were located by hand. The remaining landmarks were defined relative to these

Number Landmarks

1. The highest point of lateral femoral condyle

2. The lowest point of lateral femoral condyle

3. The highest point of femoral intercondylar notch

4. The lowest point of medial femoral condyle

5. The highest point of medial femoral condyle

6. The deepest point of patellar groove

7. The point at which the line that passes through the midpoint of the segment, which was drawn from landmark 1 to landmark 2, is perpendicular to this segment

8. The point at which the line that passes through the midpoint of the segment, which was drawn from landmark 1 to landmark 7 , is perpendicular to this segment

9. The point at which the line that passes through the midpoint of the segment, which was drawn from landmark 2 to landmark 7 , is perpendicular to this segment

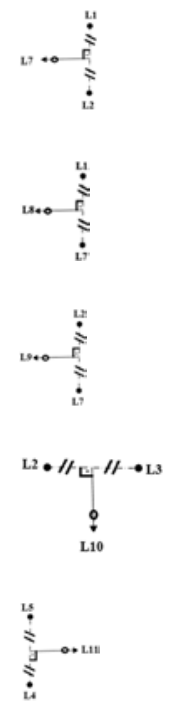

12. The point at which the line that passes through the midpoint of the segment, which was drawn from landmark 5 to landmark 11, is perpendicular to this segment

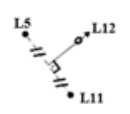

13. The point at which the line that passes through the midpoint of the segment, which was drawn from landmark 4 to landmark 11, is perpendicular to this segment

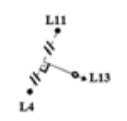

14. The point at which the line that passes through the midpoint of the segment, which was drawn from landmark 3 to landmark 4 , is perpendicular to this segment

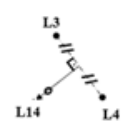




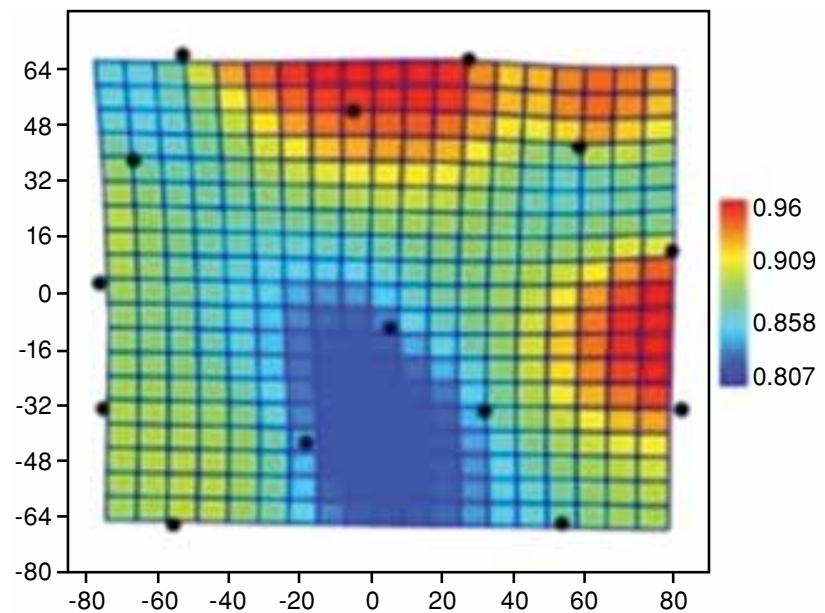

Figure 2. A thin-plate spline demonstrating the average axial shape of distal femur deformation from the control group to the study group (see text).

The thin plate spline analysis is interpreted over the landmarks used in the study, according to the change (contraction-expansion) of the grids. In figure 2, by the scaling placed on the right side of the graph, it can be understood according to the reference group contraction which occurs when it is smaller than 1, otherwise the change occurs as expansion when it is bigger than 1 . These situations are shown using the colors in Figure 2. The interpretation was made locally in accordance with this technical information.

In this study, $\mathrm{R}$ and PAST (PAleontological STatistics) 3.0 software programs were used for statistical analysis.

We calculated the intra-rater reliability coefficient for a two-facet crossed design ('landmark pairs-byrater-by-subject', $1 \times \mathrm{r} \times \mathrm{s}$ ) based on the generalizability theory (GT). In the GT, the reliability for relative (norm-referenced) interpretations is referred to as the generalizability $(G)$ coefficient. In this study, all landmarks were marked by the same investigator. After two weeks, the same investigator marked landmarks on 40 individuals (20 patients and 20 controls) randomly selected from the study population. An analysis was performed to obtain a

\section{TABLE II}

Comparison of shape differences and shape variability between groups

\begin{tabular}{lccc}
\hline Comparison & $p$ & Shape & Variability \\
\hline Patients; $(\mathrm{n}=41)$ - Controls; $(\mathrm{n}=85)$ & 0.010 & 0.111 & 0.099 \\
\hline
\end{tabular}

$\mathrm{G}$ reliability coefficient. The rating indicated a strong repeatability for patients $(G=0.9833)$ and controls $(\mathrm{G}=0.9963)$.

\section{RESULTS}

Shape differences and shape variability between groups were investigated using statistical shape analysis and presented in Table 2. There was a significant difference found between groups regarding the axial shape of the distal femur.

Procrustes mean shapes were computed for TPS (Figure 3). The deformations from control to patient group were seen in TPS graphic (Figure 2). The highest level of deformation was observed in the femoral notch area. In evaluating the distal femur in terms of shape variability on the axial plane, there was a higher level of variability in the shape of the distal femur in the study group as compared with the control group (Table 2).

\section{DISCUSSION}

In this study, we used a landmark-based shape analysis approach and focused on the female patients with knee OA and controls. The results of the current study indicate that the axial shape of the distal femur was different in the osteoarthritic female patients compared with the patients in the control group who had healthy knees. In the examination of the deformation, it showed a construction form from patients to the controls, in which the highest level of deformation was observed in the femoral notch area. Although differences were seen between the groups, there were similarities in terms of variation amongst themselves.

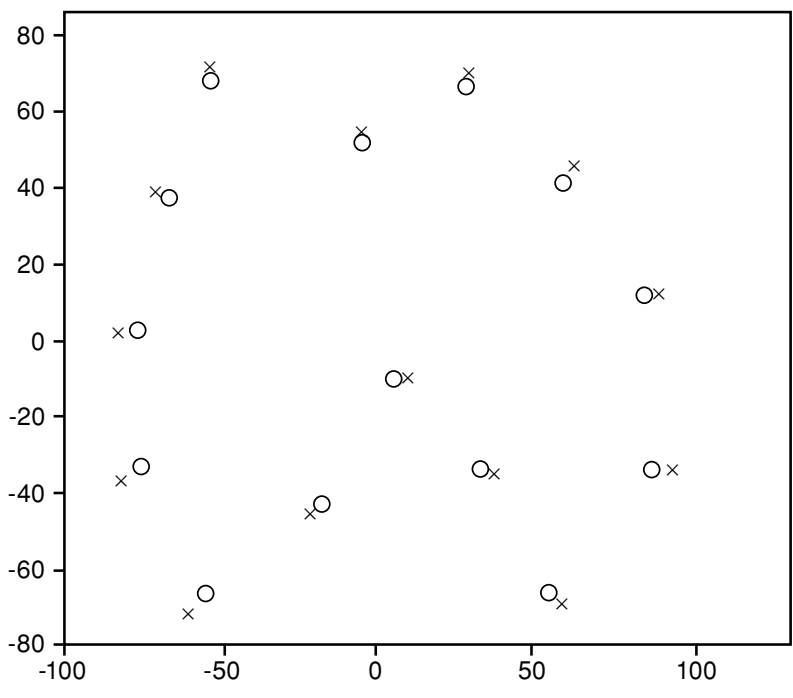

Figure 3. Procrustes mean shapes for patients (0) and controls $(x)$. 
The main reasons for the wide use of statistical shape analysis in medicine are advances in imaging technology and the tendency to investigate the effects of diseases and the environmental factors that affect the structure of the organ or organism. ${ }^{[1,7]}$ Bredbenner et al.$^{[8]}$ demonstrated in their study that quantitative differences in tibia and femur geometry were observed between surface models based on clinical MRI data of subjects who were at risk of developing $\mathrm{OA}$ and control subjects. They stated that statistical shape analysis methods provide an innovative and important step towards describing differences in knee surface and joint space geometry that may directly lead to the understanding of and differentiation between the causes and effects of OA.

The distal part of the femur has been studied extensively regarding its role on knee kinematics. ${ }^{[9,10]}$ Based on these studies, hypotheses on how to design and how to position total knee replacement implants have been proposed. Most studies about the morphometry of the distal femur are related to the examination of the linear and geometrical properties of anatomical landmarks. ${ }^{[6,9,10]}$ However, because of the axial shape difference of the distal femur that we showed, these landmarks can vary among individuals with or without knee OA. Perhaps for this reason, these landmarks when used as a reference in component placement may not provide the same accuracy component positions for all patients. ${ }^{[9,11]}$

In this study, the highest level of deformation was observed in the femoral notch area. Intercondylar notch morphology, such as notch width, notch width index, notch shape, notch area and notch outlet dimensions, have been assessed by many researchers but with different results. ${ }^{[12,13]}$ A narrow intercondylar notch has been considered a cause for damage to the anterior cruciate ligament. ${ }^{[12]} \mathrm{A}$ smaller intercondylar notch also correlated significantly with anterior cruciate ligament tear in the osteoarthritic knees. Wada et al. ${ }^{[13]}$ concluded that the intercondylar notch of the knee is significantly smaller in knees with severe OA relative to normal knees. Shepstone et al. ${ }^{[14]}$ studied human skeletons and created video images of an axial view of the distal femur and found that a flattened shape to the intercondylar notch of the femur was associated with the presence of late-stage OA. Therefore, it is reasonable to assess the relationship between the morphology of the intercondylar notch and $\mathrm{OA}$.

There are some limitations to our study. The findings cannot be generalized to men because the study includes only females. Previous studies have shown that there are differences between men and women, especially in terms of size. ${ }^{[15]}$ Additionally, the right and left knees were not compared. However, it has been emphasized recently that the knees are similar with other knees, and the variation between the right and left knees is less than inter-individual differences. ${ }^{[16]}$ On the other hand, it is not clear whether the difference that we showed is result or cause knee OA. Another shortcoming of the study is that the clinical benefits of our study are uncertain. Nevertheless, we can suppose that the surgical reference points in the axial plan for total knee arthroplasty may not be consistent for all osteoarthritic patients because of the shape deformation.

In conclusion, this study showed that shape deformations in the distal femur are present in patients with knee OA. This study is the first to show that axial shape differences of the distal femur in patients with knee OA can be evaluated using a landmark-based geometrical morphometric method by considering the topographic distribution of the distal femur. This study also reveals conformational differences in the distal femur with knee OA and suggests that the location of this difference may be a reference for future studies.

\section{Declaration of conflicting interests}

The authors declared no conflicts of interest with respect to the authorship and/or publication of this article.

\section{Funding}

The authors received no financial support for the research and/or authorship of this article.

\section{REFERENCES}

1. Ercan İ, Ocakoğlu G, Sığırlı D, Özkaya G. Statistical shape analysis and usage in medical sciences: review. Turkiye Klinikleri J Biostat 2012;4:27-35.

2. Atik OŞ. The role of metabolomics in osteoarthritis for early diagnosis, monitoring prognosis and treatment. Eklem Hastalik Cerrahisi 2015;26:1.

3. Atik OS. Is subchondral bone the crucial point for the pathogenesis and the treatment of osteoarthritis? Eklem Hastalik Cerrahisi 2014;25:1.

4. Felson DT, Lawrence RC, Dieppe PA, Hirsch R, Helmick CG, Jordan JM, et al. Osteoarthritis: new insights. Part 1: the disease and its risk factors. Ann Intern Med 2000;133:635-46.

5. Miller MC, Berger RA, Petrella AJ, Karmas A, Rubash HE. Optimizing femoral component rotation in total knee arthroplasty. Clin Orthop Relat Res 2001;392:38-45.

6. Sahin N, Atıcı T, Öztürk A, Özkaya G, Özkan Y, Avcu B. Accuracy of anatomical references used for rotational alignment of tibial component in total knee arthroplasty. Knee Surg Sports Traumatol Arthrosc 2012;20:565-70.

7. Van Haver A, Mahieu P, Claessens T, Li H, Pattyn C, Verdonk $\mathrm{P}$, et al. A statistical shape model of trochlear dysplasia of the knee. Knee 2014;21:518-23. 
8. Bredbenner TL, Eliason TD, Potter RS, Mason RL, Havill LM, Nicolella DP. Statistical shape modeling describes variation in tibia and femur surface geometry between Control and Incidence groups from the osteoarthritis initiative database. J Biomech 2010;43:1780-6.

9. Thienpont E, Schwab PE, Paternostre F, Koch P. Rotational alignment of the distal femur: anthropometric measurements with CT-based patient-specific instruments planning show high variability of the posterior condylar angle. Knee Surg Sports Traumatol Arthrosc 2014;22:29953002.

10. Griffin FM, Math K, Scuderi GR, Insall JN, Poilvache PL. Anatomy of the epicondyles of the distal femur: MRI analysis of normal knees. J Arthroplasty 2000;15:354-9.

11. Boya H, Özcan Ö, Maralcan G. An investigation of consistency between posterior condylar axis +3 degree external rotation line and clinical transepicondylar axis line techniques in primary total knee arthroplasty. Eklem
Hastalik Cerrahisi 2014;25:70-4.

12. Al-Saeed O, Brown M, Athyal R, Sheikh M. Association of femoral intercondylar notch morphology, width index and the risk of anterior cruciate ligament injury. Knee Surg Sports Traumatol Arthrosc 2013;21:678-82.

13. Wada M, Tatsuo H, Baba H, Asamoto K, Nojyo Y. Femoral intercondylar notch measurements in osteoarthritic knees. Rheumatology (Oxford) 1999;38:554-8.

14. Shepstone L, Rogers J, Kirwan JR, Silverman BW. Shape of the intercondylar notch of the human femur: a comparison of osteoarthritic and non-osteoarthritic bones from a skeletal sample. Ann Rheum Dis 2001;60:968-73.

15. Mahfouz M, Abdel Fatah EE, Bowers LS, Scuderi G. Three-dimensional morphology of the knee reveals ethnic differences. Clin Orthop Relat Res 2012;470:172-85.

16. Dargel J, Feiser J, Gotter M, Pennig D, Koebke J. Side differences in the anatomy of human knee joints. Knee Surg Sports Traumatol Arthrosc 2009;17:1368-76. 